DOI: 10.33310/2518-7813-2019-65-2-16-20

УДК 37.013.82:616.89-008.434-053.2

Лариса АРНАУтовА

кандидат медичних наук, доцент,

доцент кафедри дефектології та фізичної реабілітації

Південноукраїнського національного педагогічного університету імені К. Д. Ушинського, м. Одеса, Україна e-mail: arnautoval307@gmail.com

\title{
Любов ТАРАСЕНКО
}

магістр 1-го року навчання кафедри дефектології та фізичної реабілітації Південноукраїнського національного педагогічного університету імені К. Д. Ушинського, м. Одеса, Україна e-mail: lubavatarasenko98@gmail.com

\section{СУЧАСНІ КОРЕКЦІЙНІ ТЕХНОЛОГІЇ В РОБОТІ 3 ДІТЬМИ З ОСОБЛИВОСТЯМИ ПСИХОФІЗИЧНОГО РОЗВИТКУ}

\begin{abstract}
У статті порушено проблему навчання дітей молодшого шкільного віку з особливостями психофізичного розвитку, які вчаться в інклюзивних класах. Дослідження засноване на використання вальдорфської методики-евритмії, головною метою якої є розвиток у дитини цілісного сприймання світу через переживання його краси, гармонії, формування позитивного ставлення до себе та інших людей, удосконалення навичок спілкування. гармонізація особистості через відчуття радості, захищеності, безпеки. Було відзначено, що у дітей знижується рівень емоційної напруги. Використовувані нами вправи позитивно впливають на стан здоров'я, мислення, волю, почуття дитини і обов'язково сприяють гармонійному розвитку соціальних навичок, які у дітей з розладами аутичного спектру значно погіршені.

Ключові слова: вальфдорська педагогіка, методика евритмії, діти з розладами аутеичного спектру.
\end{abstract}

В останній час все більше приділяється уваги проблемі вивчення та корекції різноманітних порушень як психічного так і фізичного розвитку у дітей. 3'являється досить багато нової літератури, відкриваються нові методики та технології, які мають допомогти сучасним дефектологам, логопедам та звичайним вчителям найбільш вдало скорегувати то чи інше порушення, знайти індивідуальний підхід до кожного зі своїх підопічних. Невпинний розвиток педагогічної практики та зростання чисельності дітей з порушеннями зумовлює пошук нових більш ефективних методик роботи, нових підходів до організації навчальновиховного процесу.

Л. І. Кравець пише, що на хвилі зростання та популяризації ідей толерантності та гуманізму відбувається перехід від авторитарного (позиціонування дитини в ролі пасивного об'єкта педагогічного впливу) і демократичного (пристосування системи виховання до дитини, до його природі, тобто позиціонування його вже в ролі суб'єкта власного розвитку) [3]. До останнього підходу можна віднести відносно нову для України - вальдорфську педагогіку, або «педагогіку свободи» яка прийшла до нас з Німеччини. Вона представляє собою цілісну систему гуманістичного виховання i навчання. Ï̈̈ засновник - німецький педагог та вчений Рудольф Штайнер вважав, що в дитині вже закладено усі її майбутні здібності, і завданням педагога - це дати можливість розвинути їх, впливаючи на розум, волю, почуття маленької людини. Вальдорфська педагогіка відома як су- купність методів і прийомів виховання і навчання, заснована на антропософській інтерпретації розвитку людини як цілісної взаємодії тілесних, душевних і духовних чинників [6]. У зв'язку з цим задачею даної педагогічної парадигми $є$ виховання духовно вільної особистості.

Питання навчання та виховання дітей з порушеннями в розвитку у межах вальдорфської педагогіки ще не достатньо освітлене у вітчизняній науковій літературі. Зокрема даною проблемою займалися Р. Штайнер, Т. Вейс, В. Хольцапфель, Л. Дамовська, А. А. Пінський, В. К. Загвоздкін, С. А. Ловягін, та інші. Вони вважають, що штайнерівська педагогіка з її дбайливим, уважним ставленням до внутрішнього світу дитини благотворно впливає на дітей з проблемами в розвитку. Л. Дамовська зауважує, що в рамках вальдорфської педагогіки діти, які потребують корекційної навчанні, отримують необхідну увагу і допомогу з урахуванням їх особливостей [1]

3 поширенням, спочатку в європейських країнах, а згодом в СНГ вальдорфської педагогіки та зі створенням перших вальдорфських шкіл у світ прийшла нова методика - евритмія. Терапія голосом та рухом. Еврітмія не вивчається у межах традиційної системи навчання, її викладають тільки в вальдорфських школах. Поняття «евритмія» походить 3 грецької мови: ev - «прекрасний» та rytmia - «ритм». А. А. Пінський писав, що це дійсно «прекрасний ритм тіла та душі», це мистецтво руху, яке через пластичні жести, форми, відтворені в просторі, виражає внутрішній зміст музичних 
та поетичних творів. Порівнюючи звичайну гімнастику або хореографію та евритмію, остання активізує як тілесні так і душевні сили людини [4]. За переконаннями вальдорфських педагогів цей особливий вид художнього руху сприяє загальному фізичному та душевному розвитку учнів таким чином, як не може зробити ні один інший предмет.

Що ж становить цей незвичайний предмет евритмія. Це не ритміка, не гімнастика, це - мистецтво «видимої мови», «видимої музики». Воно виникло в результаті вивчення законів руху гортані, піднебіння, губ, завдяки яким людина може говорити та співати. Закономірність рухів гортані, за Р. Штайнером, можна поширити на весь людський організм. Особливо «промовистими» можуть бути руки. Тобто за допомогою жестів, рухів ми можемо, так би мовити, «побачити», те, що ми чуємо в співі та мовленні. На думку А. А. Пінського і В. К. Загвоздкина, голосні звуки виражають внутрішні переживання, тобто те, що відчуває душа, а приголосні не виражають те, що йде з глибини нашої душі, а становлять наслідування того, що оточує нас ззовні. Тобто голосний виникає із внутрішнього переживання і намагається «висловити, те чим переповнена душа, а приголосний виникає через зіткнення з речами навколишнього світу, те як ми 3 ними взаємодіємо, втілюється у приголосних звуках [6]. О. В. Язловецька також зазначала, що евритмія сприяє координації дитячих ритмічних рухів, розвитку музичного слуху, образотворчих здібностей, уяви, фантазії [7].

Головною метою евритмії $є$ розвиток у дитини цілісного сприймання світу через переживання його краси, гармонії, розвиток уміння слухати музику та рухатися під неї, орієнтуватися у просторі; формування позитивного ставлення до себе та інших людей, удосконалення навичок спілкування, гармонізація особистості через відчуття радості, захищеності, безпеки. Для досягнення цієї мети потрібно вирішувати зазначені нижче основні завдання:

1. Формувати у дітей осмислене ставлення до простору за допомогою руху по простим формах.

2. Знайомити учнів з певними жестами, що відповідають звукам української мови.

3. Формувати уміння повторювати дії вчителя

4. Зміцнювати здоров'я дітей.

5. Формувати впевненість у власних силах та можливостях.

6. Виховувати соціальну толерантність [5].

Розглядаючи особливості організації навчально-виховного процесу, то в перших класах учні займаються евритмією під музичний супровід. Діти виконують евритмічні вправи, спеціальні рухи для голосних та приголосних разом із вчите- лем у формі доступної цікавої гри. Тренування відбувається на маленьких віршах і казкових іграх, побудованих на римі та ритмі. Потрібно ритмічно відбивати такт віршів, вимірюючи його розмір короткими та довгими кроками. На уроці 3 евритмії діти привчаються вільно рухатися по заданій траєкторії. Вони пробігають прості геометричні фігури і основна увага повинна приділятися тому, щоб дитина, за допомогою відчуття тіла, змогла відчути різницю між прямою та вигнутою лінією. Таким чином, учні вчаться сприймати прості ритми в мові та музиці і знайомляться з прямою, дугою, хвилею, спіраллю. За допомогою пластичних жестів діти вчаться рухатися в просторі, співставляючи рухи з настроєм музики. Завданням вчителя на цьому етапі - будування заняття 3 урахуванням індивідуальних особливостей та можливостей кожної дитини, створення безпечного та комфортного середовища для пересування та зацікавлення дітей до активної участі в уроці. У другому класі діти також продовжують освоєння простору, засвоюють через рух вже більш складні геометричні форми та вчаться ввічливо і толерантно відноситися один до одного. Тепер вчитель відпрацьовує з учнями дзеркальні фігури, різні види кроків та рухів. Використовують предметний матеріал (дерев'яні або мідні палички) для виконання певних вправ. Це дозволяє розвивати спритність та координацію. А вправи, де діти стоять один проти одного, повторюючи рухи партнера - формують навички взаємодії. 3 погляду вальдорфської педагогіки, заняття з евритмії сприяють гармонізації особистості, темпераменту, емоційної сфери дитини, що $є$ важливим для дітей із особливостями психофізичного розвитку. У третьому та четвертому класі вчитель продовжує працювати з ритмом, розпочинає роботу з парними і загальними формами, велика увага приділяється роботі з формою спіралі. Виконуючи вправи 3 паличками, звертається увага на координацію рухів, оволодіння простором і самоконтроль, розвиток точності рухів, спритності. Розпочинають більш диференційовану роботу з музикою та поезією [5]. Є. С. Іванов зазначав, що метою еврітмії $\epsilon$ надання дитині з відхиленнями певних рамок, в яких вона змогла б реалізувати свої можливості, які для однолітків 3 нормальним розвитком $\epsilon$ природним видом комунікації, і таким чином створити патерн діалогічного спілкування для подальшого мовного розвитку.

Адже музикою в поєднанні з рухами можна виразити жестове запрошення, відгук, повторити фразу та висловити настрій набагато краще та яскравіше ніж звичайною розмовною мовою. Обмін інформацією здійснюється за допомогою мови рухів тіла, контакту очей, вокалу, і головне - 
зорової зосередженості на об'єктах, розміщених між дитиною - аутистом і дорослим.

На сьогодні евритмія ефективно використовується для поліпшення стану дітей з різним ступенем тяжкості захворювання і різним рівнем інтелекту. Даний предмет є частиною шкільного навчального плану, він як би «прокладає шлях» для навчання іншим дисциплінам, а це, в свою чергу, буде формувати цілісну систему шкільної інтеграції. Більш здібні діти, пройшовши через цю терапію можуть повернутися в масові школи, де допомога їм вже буде надаватися за допомогою інших методик, які на більш високому рівні розвивають соціальну емпатію і соціальну адаптацію. Для менш здібних дітей, наявність більш високого ступеня комунікації, також дозволить досягти великих успіхів у навчанні та соціалізації [2].

Наше дослідження полягає у висвітленні змісту вальдорфської методики - еврітмії, в роботі 3 дітьми з вадами психофізичного розвитку у межах вальдорфської школи та проведенні діагностування координаційних навичок дітей. Дану методику можливо використовувати в будь-якому навчально-виховному закладі, в практиці роботи логопеда, корекційного педагога, та музикальних педагогів, які працюють з дітьми з порушеннями.

Нами була проведена діагностика корекції навичок координації, орієнтації у просторі, рівня розвитку загальної та дрібної моторики з дітьми молодшого шкільного віку з особливостями психофізичного розвитку, які вчаться в інклюзивних класах вальдорфської школи. Діагностика проводилась перед початком та в кінці серії занять 3 евритмії, щоб з'ясувати ефективність підібраних вправ та тенденцію розвитку дитини.

В обстеженні взяли участь 10 дітей молодшого шкільного віку з особливостями психофізичного розвитку. Діагностика проводилася у формі тестування 3 використанням вправ, спеціально адаптованих для занять з евритмії на основі вимог щодо підготовки учнів молодшого шкільного віку з предмету «евритмія» за програмою для вальдорфських шкіл України, з урахуванням індивідуальних особливостей учнів.

1. Орієнтація в просторі:

- Розрізнення понять « праворуч - ліворуч», «вгору - вниз»; «вперед - назад» (самостійно та за прикладом вчителя).

- Виконання кроків на різних поверхнях стопи: на носках, на п'ятках, з зовнішньому та з зворотному боці стопи.

2. Знайомство з частинами власного тіла:

- Розпізнавання частин свого тіла: вчитель спочатку називає частини тіла - дитина показує, потім вчитель торкається частини тіла дитина, а вона називає її: голова (очі, вуха, ніс, рот), права/ліва рука, правий/лівий лікоть, права/ ліва долоня, тулуб, права/ліва нога, праве/ліве коліно, стопи, п'ятки.

3. Робота з якостями руху: розрізнення якості руху: гучно - тихо; короткі - довгі кроки; швидко - повільно (самостійно та за прикладом).

4. Робота з формами в просторі:

- Дитина стає у коло з іншими дітьми.

- Рухається в колі за напрямком руху або в бік, за формами: видозміненого кола: пряма, дуга, спіраль; рухається за формами із дзеркальною симетрією; в протилежних напрямках (широко вузько).

- Рухається за формами як індивідуально, так і групою: по прямій, по колу та овалу; за формою вісімки, за квадратом, ромба, трикутника за формою дуги, петлі; за комбінованою формою, що складається з прямих та дуг.

- Рухається свідомо «спиною вперед» у кругових формах.

5. Вправи на стан розвитку моторики:

- Дитина кидає та ловить великий та маленький м'яч.

- Перекидування м'яча або мішечка з крупою 3 руки в руку.

- Хлопок долонями над ногою і під ногою (сидячи, стоячи та при ходьбі), перед собою та за спиною.

6. Вправи на рівновагу:

- Утримування рівноваги на лавці або переступаючи наприклад з каменю на камінь.

- Пересування рівно по намальованій лінії (можна ускладнити, та покласти мішечок з крупою на голову - необхідно йти по лінії і одночасно утримувати мішечок).

Оцінка здібностей учнів оцінка проводилася за бальною системою, за якою:

- 1-3 бали - низький рівень: дитина не розуміє інструкцію, виявляються труднощі при виконанні вправи як самостійно так і за підказкою вчителя.

- 4-7 балів - середній рівень: дитина чує та розуміє інструкцію, виконує вправу з помилками, але виправляє після підказок вчителя.

- 8-10 балів - високий рівень: дитина рухається плавно, чує та розуміє інструкцію , виконує вправу без помилок та підказок вчителя.

Первинна діагностики перед початком корекційних занять показала наступні результати: 5 дітей з 10 показали низький рівень розвитку координаційних навичок, 3 - середній і 2 учня - високий рівень.

За результатами проведення серії занять 3 евритмії нами було відзначено, що у дітей знижується рівень емоційної напруги, вправи загально позитивно впливають на стан здоров'я, мислення, волю, почуття дитини і обов'язково сприяють гармонійному розвитку соціальних навичок, які у 
дітей з розладами аутичного спектру значно погіршені.

Повторна діагностика після проведення серії корекційних вправ показала, що 3 учнів показали високий рівень здібностей. Тобто вони навчилися слухати і розуміти інструкцію вчителя, виконувати вправи зразу після слів педагога та без помилок, швидко орієнтуватися у поняттях «праворуч - ліворуч», «вгору - вниз»; «вперед - назад», розрізняти якості руху «гучно - тихо; короткі - довгі кроки; швидко - повільно» (самостійно та за прикладом); виконувати кроки на різних поверхнях стопи; розпізнавати частини тіла самостійно за назвою та показом, утримувати рівновагу при виконанні вправ на лавці та під час руху за формами, точно ловити і кидати м'яч, рухатися по чітко заданій траєкторії як самостійно, так і в групі.

П’ятеро дітей з середнім рівнем здібностей загалом виконували вправи якісно та правильно, але тільки після повторної інструкції; оволоділи навичками точно ловити і кидати великий та маленький м'яч; виконувати кроки на різних поверхнях стопи; орієнтуватися у поняттях «праворуч - ліворуч», «вгору - вниз»; «вперед - назад»; вільно рухатися по лінії та простим формам, але мали труднощі під час руху за складними (спіраль, комбіновані форми) та при виконанні вправ на рівновагу.
Тільки 2 учні не поліпшили свої показники і залишилися на низькому рівні здібностей. Вони потребували постійного супроводу під час виконання вправ; виконували завдання з помилками навіть після підказок вчителя; не оволоділи навичками самостійного орієнтування у поняттях, які позначають, напрями у просторі, якості руху (тільки за прикладом); навчилися рухатися по простим формам (пряма, коло, дуга) самостійно, але мали складнощі під час руху в групі; загалом зазнавали труднощів при взаємодії з іншими учнями.

Підкреслюючи те, що діти мають особливості психофізичного розвитку і засвоєння потрібних знань, формування необхідних навичок та здібностей відбувається значно повільніше ніж у нормальної дитини, можемо зробити висновок, що евритмічні заняття мають свою ефективність. Але для отримання успішного результату потрібно дотримуватися системності занять, підтримувати їх високе відвідування, формувати у дітей позитивний емоційній стан і сталий інтерес до уроку. Необхідно поєднувати створення атмосфери доброзичливості, допомоги та взаємодопомоги і водночас вимагати чіткості та правильності виконання рухів та вправ.

\section{Списоквикористаних джерел}

1. Дамовска Л. Вальдорфская педагогика и дети, нуждающиеся в коррекционном обучении // Современное дошкольное образование. - 2013. - №6. - с. 78

2. Иванов Е.С., Демьянчук Л.Н., Демьянчук Р.В. Детский аутизм: диагностика и коррекция. - СПб.: «Дидактика Плюс», 2004. - с. 29-31

3. Кравець Л.І. Методологічні засади альтернативної освіти у сучасній педагогічній науці // Наукові записки. Серія: педагогіка. - 2014. - № 1- с.165-166

4. Пинский А. А. Вальдорфская педагогика: Антология/ Пинский А.А., В.К. Загвоздкин, С.А. Ловягин. - М.: Просвещение, 2003 - с. $402-405$

5. Програми для вальдорфських шкіл України: 1-4 кл. / М-во освіти і науки України, Департамент заг. серед. та дошк. освіти. Ін-т інновац. технологій і змісту освіти, Міжнародна Асоціація вальдорфських шкіл. - Киів.: Генеза, 2008. c. $185-186$

6. Штайнер Р. Общее учение о человеке как основа педагогики / Р. Штайнер.- М.: Парсифаль.- 1999. - 399 с.

7. Язловецька О.В. Вальдорфська педагогіка як оздоровча система /О. В. Язловецька // Наукові записки КдПУ. Серія: Педагогічні науки. - Кропивницький : КДПУ ім. В. Винниченка, 2017. - № 150. -с.127-128

\section{References}

1. Damovska L. Waldorf pedagogy and children in need of remedial education // Modern preschool education. 2013. - №6. - p. 78.

2. Ivanov E. S., Demyanchuk L. N., Demyanchuk R. V. Children's autism: diagnosis and correction. -- SPb.: «Didactics Plus», 2004. - p. 29-31

3. Kravets L. I. Methodological foundations of alternative education in modern pedagogical science / / scientific notes. Series: pedagogy. - 2014. - № 1-p. 165-166

4. Pinsky A. A. Waldorf pedagogy: an anthology / by A. A. Pinsky, V. K. Zagvozdkin, S. A. Lovyagin. - Moscow: Education, 2003 - p. 402-405

5. Programs for Waldorf schools of Ukraine: 1-4 CL. / Ministry of education and science of Ukraine, Department general and pre-school education. In-t innovats. technologies and content of education, international Association of Waldorf schools. - Kiev.: Genesis, 2008. - p. 185-186

6. Shteiner R. General doctrine of man as the basis of pedagogy / R. Shteiner.- M.: Parsifal.- 1999. - 399 p.

7. Yazlowiecka O. V. Waldorf pedagogy as a health system / Yazlowiecka O. V. // Scientific notes of KDPU. Series: Pedagogical Sciences. - Kropivnitsky : KDPU named after V. Vinnichenko, 2017. - №150. - p. 127-128 
Лариса Арнаутова, Любовь Тарасенко. Современные коррекционные технологии в работе с детьми с особенностями психофизического развития

В статье рассматривается проблема обучения детей младшего школьного возраста с особенностями психофизического развития, которые учатся в инклюзивных классах. Исследование основано на использование вальдорфской методики - евритмії, главной целью которой является развитие у ребенка целостного восприятия мира через переживания его красоты, гармонии, формирования позитивного отношения к себе и других людей, совершенствованию навыков общения, гармонизация личности через ощущение радости, защищенности, безопасности. Было отмечено, что у детей снижается уровень эмоционального напряжения. Используемые нами упражнения положительно влияют на состояние здоровья, мышление, волю, чувства ребенка и способствуют гармоничному развитию социальных навыков, которые у детей с расстройствами аутичного спектра значительно ухудшены.

Ключевые слова: вадьфдорская педагогика, методика эвритмии, дети с расстройствами аутичного спектра.

Larysa Arnautova, Liubov Tarasenko. Modern correctional technologies in work with features of psychophysical development children

The problem of teaching children of primary school age with the peculiarities of psychophysical development, who study in inclusive classes the article deals. The continuous development of pedagogical practice and the growth of the number of children with disabilities leads to the search for new more effective methods of work, new approaches to the organization of the educational process. The study is based on the use of Waldorf methodology - eurythmia, the main purpose of which is to develop a child's holistic perception of the world through the experience of its beauty, harmony, the formation of a positive attitude to themselves and other people, improving communication skills, harmonization of personality through a sense of joy, security and safety. Eurythmy is effectively used to improve the condition of children with different severity degrees of the disease and different levels of intellect. This subject is part of the school curriculum, as it «paves the way» for teaching other disciplines, and this, in turn, will form an integral system of school integration. A feature of the educational process organization in the first grade is that learners are engaged in eurythmia with music. They perform eurythmic special exercises for vowels and consonants with the teacher in the form of an accessible interesting play games. Training takes place on small poems and fairy-tale games, built on rhyme and rhythm. It is necessary to beat the rhythm of poems rhythmically, measuring its size in short and long steps. It was noted that the level of emotional stress in children is reduced. The exercises we use have a positive impact on the health, thinking, will, feelings of the child and contribute to the harmonious development of social skills, which in children with autism spectrum disorders are significantly impaired. The children learned to listen and understand the instruction of the teacher to perform the exercises immediately after the words of the master and without errors, quickly navigate in the concepts of «rightleft», «up and down»; "back and forth», to distinguish the quality of movement «loud-quiet, short-long steps; fastslow»; follow the steps on different surfaces of the foot; to recognize parts of the body to maintain balance while performing exercises on the bench and while driving on the forms to catch and throw the ball to move along defined trajectories independently and in a group. It is necessary to adhere to the systematic training and to form a positive emotional state in children and a steady interest in the lesson to obtain a successful result. It is necessary to combine the creation of an atmosphere of goodwill, assistance and mutual assistance and at the same time require clarity and correctness of the movements and exercises.

Keywords: Waldorf pedagogy, methodology of eurythmy, children with disorders of the autism spectrum. 